\title{
The significance of trade credit for micro and small enterprises
}

\author{
Katarzyna Ziętek-Kwaśniewska*
}

\begin{abstract}
Purpose - This paper aims to assess the significance of trade credit - as a source of finance - for micro and small enterprises in Poland.

Design/methodology/approach - This article reviews literature related to trade credit use by enterprises, with particular attention paid to its significance for micro and small businesses. The paper employs data from the Central Statistical Office of Poland (CSO) to assess the scale of trade credit use by small businesses in Poland. In this paper, the author also presents the results of her own research conducted on a sample of microenterprises from Lubelskie Province.

Findings - Analysis of CSO data confirms the significant position of liabilities from deliveries and services in the short-term liabilities of small enterprises in Poland. The results of the author's own research provide evidence that trade credit is of significant importance to its users. Analysis of reasons for not using trade credit by micro-enterprises suggests their mainly demand-side nature.

Originality/value - Although the use of trade credit is widespread and it has been the subject of comprehensive research, there is a shortage of studies investigating trade credit use by micro and small enterprises in Poland. By empirically examining this issue, this article makes a contribution to the literature on trade credit.
\end{abstract}

Keywords: trade credit, source of finance, micro-enterprise

\section{Introduction}

As Carbó-Valverde et al. (2016, p. 114) note, "Trade credit is ubiquitous". The great popularity of trade credit in business transactions has been well documented in numerous research studies (e.g. Wilson, Summers, 2002; Huyghebaert, 2006; García-Teruel, Martínez-Solano, 2010). According to the Atradius Payment Practices Barometer, on average $46 \%$ of the overall value of B2B sales in the Asia-Pacific region ${ }^{1}$ (Atradius, 2016a), $41.3 \%$ in Western Europe $^{2}$ (Atradius, 2016d), 39.8\% in Eastern Europe ${ }^{3}$ (Atradius, 2016b), and 43\% in the Americas $^{4}$ (Atradius, 2016c), were made on credit terms. As is noted in the Survey on the

\footnotetext{
* PhD, Katarzyna Ziętek-Kwaśniewska, The John Paul II Catholic University of Lublin, Institute of Economics and Management, Al. Racławickie 14, 20-950 Lublin, e-mail: kwasniewska@kul.lublin.pl.

${ }^{1}$ Australia, China, Hong Kong, India, Indonesia, Japan, Singapore, Taiwan.

${ }^{2}$ Germany, Austria, Denmark, Great Britain, the Netherlands, Sweden, Switzerland, Ireland, Belgium, France, Greece, Spain, Italy.

${ }^{3}$ Czech Republic, Hungary, Poland, Slovakia, Turkey.

${ }^{4}$ Brazil, Canada, Mexico, the United States of America.
} 
access to finance of enterprises (SAFE) (van der Graaf et al., 2016), trade credit was mentioned as one of the most relevant sources of external financing by EU-28 SMEs. ${ }^{6}$

Although the use of trade credit is widespread and has been the subject of comprehensive research, there are still issues requiring in-depth exploration. One such problem is the importance of trade credit as a source of finance for micro and small businesses in Poland. In particular, financial literature regarding the problem of trade credit use by micro-enterprises remains scarce.

The aim of this article is to assess the significance of trade credit - as a source of finance - for micro and small enterprises in Poland. In the paper, the author pays particular attention to the issue of trade credit use by micro-enterprises. While micro-enterprises are a dominant group of enterprises, ${ }^{7}$ there is still a gap in our knowledge about their behaviour and decision making. Therefore, by empirically examining the issue of trade credit use by micro and small enterprises, this article makes a contribution to the literature concerning the above area.

The reminder of this paper is organised as follows. Section 1 of this article presents data sources and research methods. Section 2 discusses - based on a literature review - trade credit as a source of finance for small businesses. Section 3 presents the results of an empirical study. The paper ends with concluding remarks.

\section{Data sources and research methods}

The article is based on a review of domestic and foreign literature on the topic in question. The paper employs Central Statistical Office of Poland (CSO) data to assess the scale of trade credit use by small businesses in Poland. In this paper, the author also presents the results of her own research. ${ }^{8}$ The research was conducted on a sample of 81 micro-enterprises from Lubelskie Province in the period from December 2014 to April 2015. In terms of their principal activity, the majority of the surveyed businesses were operating in wholesale and retail trade; repair of motor vehicles and motorcycles $(24.7 \%)$, other service $(23.5 \%)$, and the construction (14.8\%) sectors.

\footnotetext{
${ }^{5}$ Survey round was conducted between 19 September and 27 October 2016 (United Kingdom: 31 October).

${ }^{6} 35 \%$ of SMEs in the EU-28 considered trade credit to be relevant to their firm. In Poland, this percentage was even higher, reaching 44\% (Survey on the access..., 2016).

${ }^{7}$ In 2015 , micro-enterprises represented $96.0 \%$ of all non-financial enterprises in Poland (Central Statistical Office, 2016a).

${ }^{8}$ The results presented in this paper are part of a larger survey on trade credit payments by micro-enterprises. The results of this survey are contained in the author's doctoral dissertation (Trade credit payments by micro-enterprises, Warsaw School of Economics, Warsaw 2015).
} 


\section{Trade credit as a source of finance for micro and small businesses - literature review}

Trade credit occurs "whenever a buyer defers payments to his suppliers" (Huyghebaert, 2006 , p. 305). From the supplier's perspective, granting of trade credit results in trade receivables, for the buyer, in turn, trade credit serves as an external source of finance.

Trade credit is considered to be one of the largest sources of finance for many businesses (Tsuruta, 2013). It is noted that trade liabilities are an important source of finance (though not all theories include them in the structure of capital), and often the only available, significant source of debt (Kreczmańska-Gigol, 2014). The attractiveness, and hence popularity and common use of trade credit as a source of finance, stems from several features. The advantages of this source of finance include, in particular, the easy availability of trade credit, as well as its informal, spontaneous and flexible character (Khan, Jain, 2007).

Review of finance literature provides many reasons for entrepreneurs to use trade credit in B2B transactions, for suppliers to extend trade credit and customers to buy on credit terms. On the demand side, for example, Seifert et al. (2013) identify three major trade credit motives: transaction pooling, credit rationing, and control protection. According to the first one, trade credit is an instrument that facilitates trade as it serves as "a contractual alternative to immediate money use" (Seifert et al., 2013, p. 250). The second one refers to the problem of credit rationing, when banks - due to information asymmetry - are unable to distinguish risky borrowers from safe ones. The last one - control protection - means that suppliers, wishing to maintain a lasting relationship in the product market, make more concessions to buyers who are in financial distress compared to lenders in competitive credit markets (for this reason trade credit commonly involves a higher cost that institutional credit) (Seifert et al., 2013). Pawlowska and Marzec (2013) distinguish the two following motives in the trade credit research: the commercial (trading) motive (facilitating the exchange of goods), and the financial motive (an alternative to the bank credit source of financing), while Zawadzka (2009) mentions such motives of trade credit use as the transaction motive, the financing motive, product quality verification, financial benefit, and operational considerations.

However, regardless of how the motives for trade credit use are classified, it is often emphasised that due to the specific nature of small businesses, trade credit appears to be of particular importance for these entities. Peel et al. (2000) note that small firms - compared to large ones - are less liquid, exhibit more volatile cash flows and profits, rely to a greater extent on short-term debt-funding, and are more likely to be credit rationed. Zawadzka (2009) points out that small businesses have relatively limited access to financial markets and thus limited opportunities to efficiently satisfy their demand for funds. According to the micro-enterprise sector, it is noted that it is a specific group of entities having their own set of rules, encountering different problems than large or even medium and small businesses (Harasim, 2010). In particular, micro-business owners face the problem of time and 
resource limitations. As they have to play multiple roles simultaneously, they do not have enough time and the necessary resources to gain sufficient financial knowledge (Hassman et al., 2013).

What lies behind the credit rationing problem is the information opacity of small businesses. As Berger and Udell (2002, p. F32) note, "the informational wedge between insiders and outsiders tends to be more acute for small companies, which makes the provision of external finance particularly challenging". In the same vein, Hassman et al. (2013) state that what makes it difficult for micro-businesses to get suitable credit is that they are "informationally opaque" because of the existence of asymmetric information between them and the bank.

As suppliers may have an advantage over specialised financial institutions, such as banks, in evaluating and controlling the credit risk of their customers (Huyghebaert, 2006), trade credit can be seen as alleviating the financial constraints encountered by small businesses.

The role of trade credit for small firms has been widely discussed in financial literature. For example, Petersen and Rajan (1997) argue that small firms use more trade credit when institutional credit is unavailable. Wilson et al. (1997), based on a survey of 341 UK small owner-managed businesses, suggest that trade credit is often used as a source of short-term finance for small and growing firms that are rationed for institutional credit. Danielson and Scott (2004) found that U.S. small businesses increased their demand for trade credit and credit card debt when facing bank credit constraints. The results of Huyghebaert (2006), in turn, show that start-ups that are financially constrained, both internally (measured by internal cash production) and externally (measured by the cost of bank debt), use more trade credit.

In Polish literature, there is not much research work on trade credit use by small firms. In particular, the issue of trade credit use by Polish micro and small enterprises was the subject of research conducted by Zawadzka (2009). Her results confirm large interest in the trade credit use in the group of Polish micro and small enterprises. They show that $90.0 \%$ of micro and $97.0 \%$ of small enterprises declared the use of trade credit in transactions with suppliers, and - respectively $-48.0 \%$ and $64.0 \%$ reported its use in at least half of all transactions. Extensive research conducted by Zawadzka (2009) provided support to the thesis that the demand of small businesses for trade credit was to a greater extent determined by transaction motives, while decisions about late payment were mainly influenced by financing motives.

The results of research made by Pawlowska and Marzec (2013) made it possible to positively verify the hypothesis about a significant relationship between trade credit and bank credit. The authors identified a substitution between these two sources of financing enterprises' current activities. Significantly, their results indicate that the substitution of trade credit and bank credit concerned to a greater extent small companies rather than large ones. 


\section{The significance of trade credit for Polish micro and small enterprises - research results}

According to CSO data, at the end of 2015 short-term liabilities occupied a dominant position in the structure of liabilities and provisions for liabilities of Polish small enterprises with a share of $57.3 \%$. An analysis over the period 2008-2015, however, reveals a decrease in the share of short-term liabilities in liabilities and provisions for liabilities in recent years - from $63.8 \%$ in 2008 to the above-mentioned $57.3 \%$ in $2015^{9}$.

In order to assess the significance of trade credit for small enterprises in Poland, the structure of the short-term liabilities of these entities was analysed. The results confirm the importance of trade credit as a short-term source of finance for small entities (Figure 1). As of December 31, 2015, the share of liabilities from deliveries and services in short-term liabilities was $45.9 \%$, while the share of credits and loans was $30.8 \%$. The analysis for the years 2008-2015 indicates, however, that during this period the share of liabilities from deliveries and services in short-term liabilities decreased by five percentage points. In the period under analysis, the share of credits and loans in the short-term liabilities of small enterprises was also subject to fluctuation. While in 2010 it was $23.3 \%$ (the lowest share in the period in question), at the end of 2015 it was 7.6 percentage points higher. Comparing the amount of liabilities from deliveries and services with the amount of credits and loans, a change in their relationship is noted - while in 2009 and 2010 liabilities from deliveries and services were more than double the short-term liabilities due to credits and loans, at the end of 2015 this ratio was equal to $1.49 .^{10}$

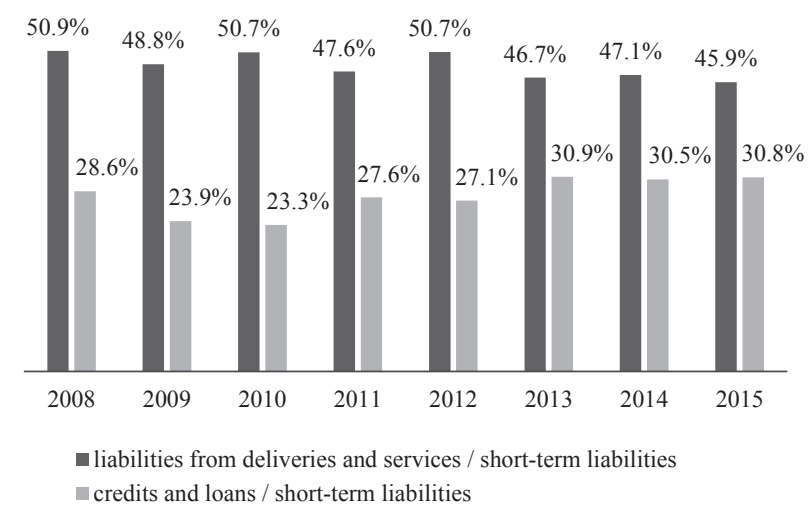

Figure 1. Share of liabilities from deliveries and services and credits and loans in the short-term liabilities of small enterprises in Poland in the years 2008-2015

Source: own elaboration based on CSO data (Central Statistical Office, 2009, 2010, 2011, 2012, 2013, 2014, 2015, 2016b).

\footnotetext{
${ }^{9}$ Own calculations based on CSO data (Central Statistical Office, 2009, 2010, 2011, 2012, 2013, 2014, 2015, 2016b).

${ }^{10}$ Own calculations.
} 
The issue of trade credit use by micro-enterprises was the subject of the author's own research. As indicated by the research results, $79.0 \%$ of respondents admitted to the use of trade credit in transactions with suppliers (with varying frequency). The rest of them declared that they never made purchases on credit terms.

As mentioned earlier, a number of studies have reported the importance of trade credit for smaller entities that may have difficulty accessing external financing. Nevertheless, there is a lack of research on how micro-enterprises themselves perceive the significance of trade credit for their business activity. Therefore, in order to investigate this question, respondents who declared buying on credit terms were asked to assess the importance of trade credit for their business activity. Table 1 summarises the answers of trade credit users to the above question.

\section{Table 1}

The importance of trade credit for surveyed micro-enterprises (\%) ${ }^{*}$

\begin{tabular}{lr}
\hline The opportunity to purchase goods/services with deferred payment term & \\
\hline Is necessary for the proper functioning of the enterprise & 26.6 \\
Is not necessary, however, it significantly facilitates the functioning of the enterprise & 45.3 \\
Slightly facilitates the functioning of the enterprise & 20.3 \\
Has no impact on the enterprise - neither helps nor harms & 7.8 \\
Does more harm than good & 0.0 \\
\hline "The percentages in the group of respondents who declared using trade credit. & \\
Source: author's own research.
\end{tabular}

As indicated in Table 1, trade credit plays an important role for the surveyed micro-enterprises. Over $92.0 \%$ of trade credit users admitted that the opportunity to purchase goods/ services with deferred payment term facilitated the functioning of the enterprise, while more than one in four of them perceived trade credit as necessary for the proper functioning of the firm. Mostly, the trade credit users stated that although such an opportunity was not necessary for them, it greatly facilitated the functioning of the enterprise (45.3\%). Only $7.8 \%$ of trade credit users said that the opportunity to make purchases on credit terms had no impact on the enterprise.

While many studies concern the motives for trade credit use, little is known about why some enterprises do not use it. This issue, however, seems to be no less important than the determinants of buying on credit terms. Therefore, in examining the reasons underlying such behaviour, the respondents were asked: What are the reasons that the micro-enterprise does not use trade credit - whether in certain transactions with suppliers or at all. Table 2 presents the obtained results. 


\section{Table 2}

Reasons for not using trade credit by surveyed micro-enterprises $(\%)^{*}$

\begin{tabular}{lr}
\hline Reason & \\
\hline No need for trade credit & 55.6 \\
Aversion to being a debtor & 43.2 \\
Preference for immediate payment due to possibility of obtaining a cash discount & 24.7 \\
Being refused trade credit & 24.7 \\
Insufficient credit terms offered by supplier & 12.3 \\
Others & 1.2 \\
\hline
\end{tabular}

"The answers do not sum to $100 \%$. Respondents could choose up to three answers.

Source: author's own research.

As exhibited in Table 2, "no need for trade credit" was cited as the number one reason for not using trade credit $(55.6 \%) .{ }^{11}$ What, however, attracts attention is that $43.2 \%$ of respondents pointed out "aversion to being a debtor" as a determinant for not buying on credit terms. Other reasons, such as preference for immediate payment due to the possibility of obtaining a cash discount, refusal of trade credit, insufficient credit terms offered by supplier, were of minor importance. Overall, the results suggest that the motives for not using trade credit by respondents are rather of demand than supply nature. This means that a significant proportion of the respondents consciously refrained from the use of trade credit in transactions with their suppliers.

In this context, it should be recalled that while the use of trade credit as a source of business financing has many positive attributes, it also obscures certain dangers for the debtor. If the trade debtor does not pay within the agreed period, it can be harmful for his reputation, which in turn may affect his ability to borrow or trade later.

In light of the above, one should also refer to the results presented in the Report on the situation of micro and small enterprises in the year 2016 (Bank Pekao, 2017). According to this report, key reasons for not using financing other than own funds (i.e. financing current activity of a company from own funds only) by the surveyed micro-entrepreneurs were the lack of a need for external financing (54\%) and aversion to debt (31\%). These results, together with the results of the author's own research, indicate that aversion to being a debtor is a factor that significantly influences non-use of external finance by micro-enterprises.

In the course of business, approximately $2 / 3$ of the respondents met with refusal of trade credit. Asked for the reasons for being turned down for trade credit by a supplier, ${ }^{12}$ the respondents mainly indicated a short period of cooperation and unconfirmed payment

\footnotetext{
${ }^{11}$ It is worth mentioning that according to the SAFE data, most SMEs (data for EU-28) that did not apply for trade credit cited the availability of sufficient internal funds as the most important reason for not doing so. The same was observed for Polish SMEs (Survey on the access..., 2016).

${ }^{12}$ Respondents could choose up to three answers.
} 
credibility (71.2\%). Nearly half of them pointed to the lack of any such possibility, as the supplier did not sell with deferred payment (48.1\%).

\section{Concluding remarks}

Despite the widespread use of trade credit in B2B transactions, there is not much research regarding its significance for small businesses in Poland, particularly for micro-enterprises. This paper aimed at filling this gap.

Empirical verification based on CSO data confirmed the significance of trade credit in the structure of short-term liabilities of Polish small enterprises. Despite the fact that the share of liabilities from deliveries and services in short-term liabilities has declined in recent years, they occupy a dominant position within the structure of short-term liabilities.

The results of the author's own research conducted on a sample of micro-enterprises from Lubelskie Province provide evidence that trade credit is assessed as having a significant importance to its users. Analysis of reasons behind not using trade credit, among which the most important were "no need for trade credit" and "aversion to being a debtor", suggests their mainly demand-side nature.

\section{References}

Atradius (2016a). Atradius Payment Practices Barometer. International survey of B2B payment behaviour. Asia Pacific - key survey results. Retrieved from: https:/group.atradius.com/publications/payment-practices-barometer-asia-pacific-2016.html (20.03.2017).

Atradius (2016b). Atradius Payment Practices Barometer. International survey of B2B payment behaviour. Eastern Europe - key survey results. Retrieved from: https://atradius.pl/reports/payment-practices-barometer-easterneurope-2016.html (20.03.2017).

Atradius (2016c). Atradius Payment Practices Barometer. International survey of B2B payment behaviour. The Americas - key survey results. Retrieved from: https://group.atradius.com/publications/payment-practicesbarometer-americas-2016.html (20.03.2017).

Atradius (2016d). Atradius Payment Practices Barometer. International survey of B2B payment behaviour. Western Europe - key survey results. Retrieved from: https:/group.atradius.com/publications/payment-practices-barometer-western-europe-2016.html (20.03.2017).

Bank Pekao SA (2017). Report on the situation of micro and small enterprises in the year 2016. Special topic: investment in micro and small enterprises. Warszawa: Bank Pekao SA.

Berger, A.N., Udell, G.F. (2002). Small Business Credit Availability and Relationship Lending: The Importance of Bank Organisational Structure. The Economic Journal, 112 (477), F32-F53. DOI: 10.1111/1468-0297.00682.

Carbó-Valverde, S., Rodríguez-Fernández, F., Udell, G.F. (2016). Trade Credit, the Financial Crisis, and SME Access to Finance. Journal of Money, Credit and Banking, 1 (48), 113-143. DOI: 10.1111/jmcb.12292.

Central Statistical Office (2016a). Activity of non-financial enterprises in 2015. Warsaw: CSO.

Central Statistical Office (2009). Financial results of economic entities in 2008. Warsaw: CSO.

Central Statistical Office (2010). Financial results of economic entities in 2009. Warsaw: CSO.

Central Statistical Office (2011). Financial results of economic entities in 2010. Warsaw: CSO.

Central Statistical Office (2012). Financial results of economic entities in 2011. Warsaw: CSO.

Central Statistical Office (2013). Financial results of economic entities in 2012 (balance sheet). Warsaw: CSO.

Central Statistical Office (2014). Financial results of economic entities in 2013 (balance sheet). Warsaw: CSO.

Central Statistical Office (2015). Financial results of economic entities in 2014 (balance sheet). Warsaw: CSO.

Central Statistical Office (2016b). Financial results of economic entities in 2015 (balance sheet). Warsaw: CSO. 
Danielson, M.G., Scott, J.A. (2004). Bank Loan Availability and Trade Credit Demand. The Financial Review, 4 (39), 579-600. DOI: 10.1111/j.0732-8516.2004.00089.x.

García-Teruel, P.J., Martínez-Solano, P.M. (2010). A Dynamic Approach to Accounts Receivable: a Study of Spanish SMEs. European Financial Management, 3 (16), 400-421. DOI: 10.1111/j.1468-036X.2008.00461.x.

Harasim, J. (2010). Zewnętrzne źródła finansowania mikroprzedsiębiorstw w warunkach kryzysu. Zeszyty Naukowe Uniwersytetu Szczecińskiego, 588. Ekonomiczne Problemy Ustug, 51, 71-80.

Hassman, M., Schwartz, D., Bar-El, R. (2013). Micro-enterprise lack of access to credit - The Israeli case. International Journal of Business and Economic Development, 1 (3), 1-14. Retrieved from: http://www.ijbed.org/ admin/issue/pdf/volume_67830/nv13\%201.pdf(20.03.2017).

Huyghebaert, N. (2006). On the Determinants and Dynamics of Trade Credit Use: Empirical Evidence from Business Start-ups. Journal of Business Finance \& Accounting, 1/2 (33), 305-328. DOI: 10.1111/j.14685957.2006.001364.X.

Khan, M.Y., Jain, P.K. (2007). Financial Management (5 ${ }^{\text {th }}$ ed.). New Delhi: Tata McGraw-Hill Publishing Company Limited.

Kreczmańska-Gigol, K. (2014). Kredyt kupiecki. In: J. Szlęzak-Matusewicz, P. Felis (eds.), Finansowanie przedsiębiorstwa. Ujęcie teoretyczno-praktyczne (pp. 149-167). Warszawa: Wolters Kluwer SA.

Pawlowska, M., Marzec, J. (2013). Trade Credit and Bank Credit Substitution Hypothesis: Case of the Polish Companies. In: M. Balling, E. Gnan, P. Jackson (eds.), States, Banks and the Financing of the Economy: Monetary Policy and Regulatory Perspectives. SUERF Study 2013/3 (pp. 77-111). Vienna. Retrieved from: http://www. suerf.org/docx/s_4625d8e31dad7d1c4c83399a6eb62f0c_3769_suerf.pdf (6.03.2017).

Peel, M.J., Wilson, N., Howorth, C. (2000). Late Payment and Credit Management in the Small Firm Sector: Some Empirical Evidence. International Small Business Journal, 2 (18), 17-37. DOI: 10.1177/0266242600182001.

Petersen, M.A., Rajan, R.G. (1997). Trade Credit: Theories and Evidence. The Review of Financial Studies, 3 (10), 661-691.

Seifert, D., Seifert, R.W., Protopappa-Sieke, M. (2013). A review of trade credit literature: Opportunities for research in operations. European Journal of Operational Research, 2 (231), 245-256. DOI: 10.1016/j.ejor.2013.03.016.

Survey on the access to finance of enterprises. September to October 2016 (wave 15). Summary by country. (2016). Retrieved from: http://ec.europa.eu/DocsRoom/documents/20369?locale=pl (6.03.2017).

Tsuruta, D. (2013). Customer relationships and the provision of trade credit during a recession. Applied Financial Economics, 12 (23), 1017-1031. DOI: 10.1080/09603107.2013.791016.

van der Graaf, A., Kwaak, T., van der Zeijden, P. (2016). Survey on the access to finance of enterprises (SAFE). Analytical Report 2016. Luxembourg: Publications Office of the European Union. Retrieved from: http://ec.europa. eu/DocsRoom/documents/20403 (6.03.2017).

Wilson, N., Summers, B. (2002). Trade Credit Terms Offered by Small Firms: Survey Evidence and Empirical Analysis. Journal of Business Finance \& Accounting, 3/4 (29), 317-351. DOI: 10.1111/1468-5957.00434.

Wilson, N., Summers, B., Singleton, C. (1997). Small Business Demand for Trade Credit, Credit Rationing and The Late Payment of Commercial Debt: An Empirical Study. CMRG, Management Centre, University of Bradford. Retrieved from: http:/citeseerx.ist.psu.edu/viewdoc/download;jsessionid=B64E03BE7FF73728D5974E EB97A90323?doi=10.1.1.197.7712\&rep=rep1\&type=pdf (6.03.2017).

Zawadzka, D. (2009). Determinanty popytu małych przedsiębiorstw na kredyt handlowy. Identyfikacja $i$ ocena. Poznań: Wydawnictwo Uniwersytetu Ekonomicznego w Poznaniu.

\section{ZNACZENIE KREDYTU KUPIECKIEGO DLA MIKRO I MALYCH PRZEDSIĘBIORSTW}

Streszczenie: $\mathrm{Cel}$ - Celem artykułu jest ocena znaczenia kredytu kupieckiego - jako źródła finansowania działalności - dla mikro i małych przedsiębiorstw w Polsce.

Metodologia badania - W artykule dokonano przeglądu literatury przedmiotu z zakresu wykorzystania kredytu kupieckiego przez przedsiębiorstwa, ze szczególnym uwzględnieniem jego znaczenia dla mikro i małych przedsiębiorstw. W pracy posłużono się danymi Głównego Urzędu Statystycznego (GUS) w celu oceny skali wykorzystania kredytu handlowego przez małe przedsiębiorstwa w Polsce. W pracy autorka zaprezentowała także wyniki własnych badań przeprowadzonych wśród mikroprzedsiębiorstw z województwa lubelskiego.

Wynik - Analiza danych GUS potwierdza znaczącą pozycję zobowiązań z tytułu dostaw i usług w zobowiązaniach krótkoterminowych małych przedsiębiorstw w Polsce. Wyniki badań własnych autorki dowodzą 
istotnego znaczenia kredytu kupieckiego dla jego użytkowników. Analiza powodów, dla których mikroprzedsiębiorstwa nie korzystają z kredytu kupieckiego, sugeruje, że są one głównie natury popytowej.

Oryginalność/wartość - Pomimo powszechnego stosowania kredytu kupieckiego oraz szerokich badań mu poświęconych, brakuje badań nad wykorzystaniem kredytu kupieckiego przez mikro i małe przedsiębiorstwa w Polsce. Poprzez empiryczne podjęcie tej kwestii, artykuł wnosi wkład do literatury z zakresu kredytu kupieckiego.

Słowa kluczowe: kredyt kupiecki; źródło finansowania; mikroprzedsiębiorstwo

\section{Citation}

Ziętek-Kwaśniewska, K. (2017). The significance of trade credit for micro and small enterprises. Finanse, Rynki Finansowe, Ubezpieczenia, 5 (89/1), 257-266. DOI: 10.18276/frfu.2017.89/1-21. 